\title{
ČIŠTĚNÍ ŠEDÉ VODY V LABORATORNÍCH A REÁLNÝCH PODMÍNKÁCH MEMBRÁNOVÝM BIOREAKTOREM
}

\author{
MEMBRANE BIOREACTOR TECHNOLOGY FOR GREYWATER \\ TREATMENT IN THE LABORATORY AND REAL CONDITIONS
}

\author{
Kristýna Velikovská*,1 \\ *velikovska.k@fce.vutbr.cz \\ ${ }^{1}$ Vysoké učení technické v Brně: Fakulta stavební, Ústav vodního hospodářství obcí, Veveří 331/95, 60200 Brno
}

\begin{abstract}
Abstrakt
Opětovné využití odpadních vod je jedním z významně diskutovaných témat vedoucích $\mathrm{k}$ udržitelnému hospodaření s vodou. Oddělování a recyklace odpadní vody už na úrovni domácností a dalších obytných nebo provozních objektů by mohlo být považováno za klíčový přístup novodobého koncepčního vývoje týkajícího se vnímání odpadu jako zdroje. Předmětem tohoto př́spěvku je představení a srovnání výsledků z testování membránové technologie (membránového bioreaktoru, MBR) k čištění šedé vody v laboratorních a reálných podmínkách pro účely znovuvyužití bílé vyčištěné vody na úrovni domácností.
\end{abstract}

\section{Klíčová slova}

Čištění odpadních vod, recyklace odpadní vody, šedá voda, bílá voda, membránový bioreaktor

\begin{abstract}
Wastewater reuse is one of the signs discussed topics leading to sustainable water management. Separation and recycling of wastewater already at the level of households and other residential or operational buildings could be considered as a key approach of modern conceptual development concerning the perception of waste as a resource. The aim of this paper is to present and compare the results from testing membrane technology (membrane bioreactor, MBR) for greywater treatment in the laboratory and real conditions water reuse at the household level.
\end{abstract}

\section{Key words}

Wastewater treatment, wastewater reuse, greywater, white water, membrane bioreactor

\section{1 ÚVOD}

Opětovné využití méně znečištěné šedé vody (ŠV), která je významnou složkou odpadní vody (OV), může hrát zásadní roli při přeměně OV na cenný vodní zdroj. [1][2] K opětovnému využívání OV byly stanoveny pokyny, jež předepisují limity pro kvalitu vody v závislosti na typu dalšího využití. V roce 2020 byla v České republice vydána technická norma ČSN ISO 20761 Opětovné využití vody v městských oblastech - směrnice pro hodnocení bezpečnosti opětovného využití vody - hodnocené ukazatele a metody [3], [4].

Testování čištění ŠV prostřednictvím MBR probíhalo ve dvou etapách v rámci projektu „Získávání a využití tepelné energie z odpadní vody v kombinaci s využitím vyčištěné vody“ ̌rešeného v letech 2019-2021 s podporou programu TA ČR Zéta. V první etapě bylo MBR testováno pro čištění ŠV na odtoku ze sprchového koutu v laboratoři výzkumného centra AdMaS VUT v Brně. $V$ druhé etapě bylo testováno čištění šedé vody v reálných podmínkách, tedy na odtoku z rodinného domu.

\section{KRITÉRIA KVALITY VODY}

Dle „Rámce pro hodnocení bezpečnosti opětovného využití vody v městských oblastech“ uvedeného v normě ČSN ISO 20761 [3] je kvalita vody určené pro znovuvyužití závislá na účelu využití a specificky odpovídajících 
podmínkách. Pro hodnocení bezpečnosti opětovného využití takto připravené nepitné vody je v rámci tohoto dokumentu doporučeno rozhodovací schéma znázorněné na Obr. 1.

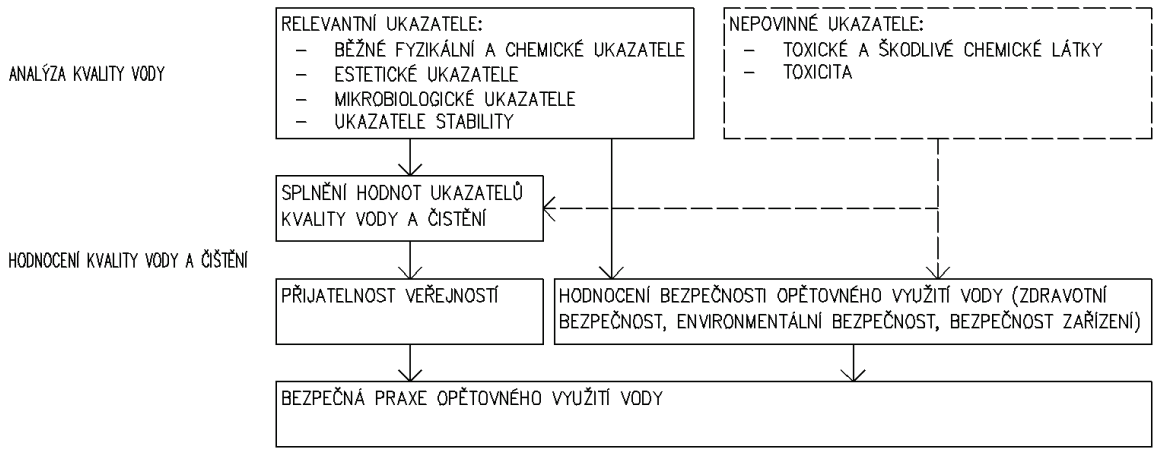

Obr. 1 Schéma rámce pro hodnocení bezpečnosti opětovného využití vody dle ČSN ISO 20761 [3], [4].

Posuzování kvality vyčištěné OV je vázáno na účel opětovného využití odpadní vody. Aplikace technologie čištění ŠV byla v rámci testování zaměřena na využití vyčištěné šedé vody k splachování toalet a zavlažování. Pro tyto účely opětovného využití jsou normou ČSN ISO 20761 doporučené ukazatele uvedené v Tab. 1 [3].

Tab. 1 Doporučené ukazatele kvality vody pro různé účely opětovného využití OV [3], [4].

\begin{tabular}{cccccccc}
\hline $\begin{array}{c}\text { Účel využití } \\
\text { vyčištěné } \\
\text { OV }\end{array}$ & pH & BSK5 & $\begin{array}{c}\text { TDS/ } \\
\text { elektrická } \\
\text { konduktivita }\end{array}$ & Zákal & $\begin{array}{c}\text { Zbytkový } \\
\text { chlor }\end{array}$ & $\begin{array}{c}\text { Indik. } \\
\text { Eakterie, } \\
\text { E-coli nebo } \\
\text { koliformní } \\
\text { bakterie }\end{array}$ & Pach \\
\hline $\begin{array}{c}\text { Splachování } \\
\text { toalet } \\
\text { Zavlažování }\end{array}$ & Ano & Ne & Ne & Ano & Ano & Ano & Ne \\
\hline
\end{tabular}

\section{TESTOVÁNÍ MBR V LABORATORNÍCH PODMÍNKÁCH}

Pro testování a ověření účinnosti čištění ŠV (ČŠV) technologickým postupem s membránovou filtrací (MBR) a byl navržen a sestaven jeden technologický (TG) celek. Zdrojem ŠV pro vstup do čisticího TG procesu byl odtok ze sprchového koutu, odkud byla ŠV odváděna do přečerpávací jednotky, která následně distribuovala ŠV přes svíčkový filtr přímo do akumulační nádrže, v níž byla umístěna membránová jednotka. Po mechanickém předčištění tedy bylo médium přiváděno na membránu, kde byly odděleny pevné složky (retentát) od permeátu. ŠV byla v tomto místě zbavena částic, které jsou větší než póry membrány.

Modul podtlakového membránového systému byl ponořen přímo do aktivační nádrže. Pod membránový modul byl přiváděn provozní vzduch zajišt’ující jemnobublinnou aeraci. Usazené látky byly $\mathrm{v}$ těchto modulech odstraňovány přiváděným pracím vzduchem společně s provozním vzduchem, a to v podobě hrubobublinných elementů. Zařazením membrány do aktivačního procesu je membránou plně nahrazena dosazovací nádrž, čímž odpadá nepř́iznivý vliv na kvalitu odtoku způsobený nedostatečnými sedimentačními vlastnostmi sekundárního kalu. [5][6]

Pro testování bylo využito kompaktní čistírny odpadních vod AS-GW/Aqualoop typu 6, s mikrofiltračním membránovým modulem s průlinami $0,02 \mu \mathrm{m}$ a provozním tlakem $0,07 \mathrm{MPa}$.

Technologie pro čištění ŠV byla v laboratoři testována 74 dní s celkovým př́tokem z 59 sprchových cyklů. Výsledky analýzy ŠV na vstupu do čistícího procesu, bílé vyčištěné vody na výstupu z technologie čištění (BV) a účinnosti čištění ( $\eta)$ jsou znázorněny v Tab. 2. 
Tab. 2 Výsledky fyzikální a chemické analýzy odpadní vody z testování v laboratorní podmínkách (legenda $-\mathrm{CH}^{*}=\mathrm{CHSK}_{\mathrm{Cr}}$ ).

\begin{tabular}{|c|c|c|c|c|c|c|c|c|c|c|c|c|c|c|c|c|}
\hline \multirow[t]{2}{*}{ OV } & \multirow[t]{2}{*}{$\begin{array}{l}\text { Uka- } \\
\text { zatel }\end{array}$} & \multirow[t]{2}{*}{ MJ } & \multicolumn{14}{|c|}{ Odběr } \\
\hline & & & 1 & 2 & 3 & 4 & 5 & 6 & 7 & 8 & 9 & 10 & 11 & 12 & 13 & 14 \\
\hline ŠV & \multirow{2}{*}{$\mathrm{pH}$} & - & 8,7 & 8,1 & 8,1 & 7,9 & 7,8 & 7,6 & 7,9 & 8,1 & 7,9 & 8,2 & 7,9 & 8,1 & 8,2 & 8,2 \\
\hline BV & & - & 8,2 & 8,4 & 8,6 & 8,2 & 8,6 & 8,7 & 8,6 & 8,6 & 8,7 & 8,5 & 8,7 & 8,5 & 8,7 & 8,6 \\
\hline ŠV & \multirow{2}{*}{ barva } & $\mathrm{Pt}$ & - & 17 & 29 & 8 & 11 & 11 & 7 & 8 & 15 & - & 42 & 52 & 47 & 82 \\
\hline BV & & $\mathrm{Co}^{-1}$ & - & 7 & 12 & 3 & 2 & 3 & 3 & 3 & 3 & 10 & 8 & 8 & 6 & 6 \\
\hline ŠV & \multirow[t]{2}{*}{ zákal } & \multirow[t]{2}{*}{$\mathrm{ZF}_{(\mathrm{n})}$} & - & 1,6 & 2,5 & 2,7 & 1,3 & 1,2 & 1,3 & 1,7 & 3,0 & 38 & 6,1 & 7,6 & 6,4 & $\begin{array}{c}14 \\
7\end{array}$ \\
\hline BV & & & - & 0,6 & 1,1 & 0,2 & 1,3 & 0,9 & 0,6 & 0,6 & 0,7 & 1,2 & 0,8 & 1,3 & 1,4 & 1,1 \\
\hline ŠV & \multirow{2}{*}{$\mathrm{BSK}_{5}$} & \multirow{2}{*}{$\mathrm{mg} \cdot \mathrm{l}^{-1}$} & 19,5 & 11,5 & 15 & 8,4 & 4,8 & 5,6 & 6,3 & 3,9 & 12 & 20 & 7,9 & 6,1 & 1,6 & 37 \\
\hline BV & & & 13 & 10,5 & 2,5 & 2,1 & 4 & 1,8 & 2,6 & 1,7 & 4,3 & 3,8 & 3,8 & 1,3 & 17 & 5,4 \\
\hline ŠV & \multirow{2}{*}{$\mathrm{CH}^{*}$} & \multirow{2}{*}{$\mathrm{mg} \cdot \mathrm{l}^{-1}$} & 120 & 80 & 90 & 40 & 48 & 40 & 102 & 58 & 118 & 368 & 190 & 106 & 48 & 134 \\
\hline BV & & & 116 & 42 & 78 & 54 & 38 & 38 & 52 & 44 & 46 & 78 & 90 & 36 & 30 & 86 \\
\hline ŠV & \multirow{2}{*}{ NL } & \multirow{2}{*}{$\mathrm{mg} \cdot \mathrm{l}^{-1}$} & 6 & 30 & 5 & 6 & 0 & 0 & 5 & 3 & 0 & 52 & 8 & 10 & 7 & 20 \\
\hline BV & & & 9 & 12 & 0 & 0 & 0 & 0 & 0 & 1 & 0 & 3 & 7 & 2 & 0 & 9 \\
\hline
\end{tabular}

Limity $\mathrm{pH}$ pro kvalitu bílé vody určené k zavlažování jsou velmi podobné $\mathrm{pH}$ př́rodních vod. Vzorky bílé vody vykazovaly zásadité $\mathrm{pH}$, přičemž hodnoty přesahují definované hodnoty $\mathrm{pH}$ v Izraeli $(\mathrm{pH} 6,5-8,5)$ a Japonsku ( $\mathrm{pH} 5,8-8,6)$. V těchto př́ípadech není hodnota $\mathrm{pH}$ dodržena v řádech desetin, případně setin. Norma ČSN ISO 20761 [3] definuje pro účely splachování bílou vodou stejné limity, jako pro její využití k zavlažování.

Barva a zákal jsou jedny z hlavních organoleptických ukazatelů, které ovlivňují přijatelnost veřejností. Limity pro tyto ukazatele jsou př́ísnější zejména při využívání bílé vody k splachování toalet. Získané hodnoty splnily výsledky analýzy bílé vody limity ukazatelů barvy i zákalu pro účely zavlažování i splachování toalet [4].

Koncentrace $\mathrm{BSK}_{5}$ vyjadřující obsah biologicky rozložitelných látek v bílé vodě využívané pro zavlažování a splachování záchodů testovaných vzorků vyhovělo normě ČSN ISO 20761 pouze částečně. Hodnoty BSK 5 v bílé vodě na výstupu z ČŠV MBR splnily limit BSK5 $\leq 10 \mathrm{mg} \cdot 1^{-1}$ pouze u $79 \%$ analyzovaných vzorků, tř̀ z testovaných vzorků přesáhly $10 \mathrm{mg} \cdot 1^{-1}$, avšak splnily podmínku BSK $5 \leq 20 \mathrm{mg} \cdot 1^{-1}$ [4].

Bílá voda po ČŠV MBR vykazovala koncentraci NL splňující limit ČSN ISO 20761 pro zavlažování, pro splachování toalet nesplnila koncentrace NL limit předepsaný ve Španělsku $\left(\mathrm{NL} \leq 10 \mathrm{mg} \cdot \mathrm{l}^{-1}\right)$ pouze v prípadě jednoho vzorku [4].

\section{TESTOVÁNÍ MBR V REÁLNÝCH PODMÍNKÁCH}

Pro testování v reálných podmínkách bylo využito navrženého prototypu z řešení projektu „Získávání a využití tepelné energie z odpadní vody v kombinaci s využitím vyčištěné vody“. Technologie čištění ŠV v rámci prototypu byla oproti laboratorní jednotce doplněna chemickým dávkováním dezinfekce a předřazenou sedimentací. Technologie čištění je znázorněna v Obr. 2. ŠV přiváděna na zařízení je mechanicky předčištěna sedimentací v akumulační nádrži ŠV (AN ŠV). Do prototypu je dále zaústěna vtokovým potrubím s nornou stěnou do nádrže MBR. V reaktoru probíhá biologické čištění za př́ístupu vzduchu z dmychadla. OV je filtrována přes podtlakovou membránovou stanici a po dávkování dezinfekce k hygienizaci permeátu přiváděna do akumulace BV (AN BV). 

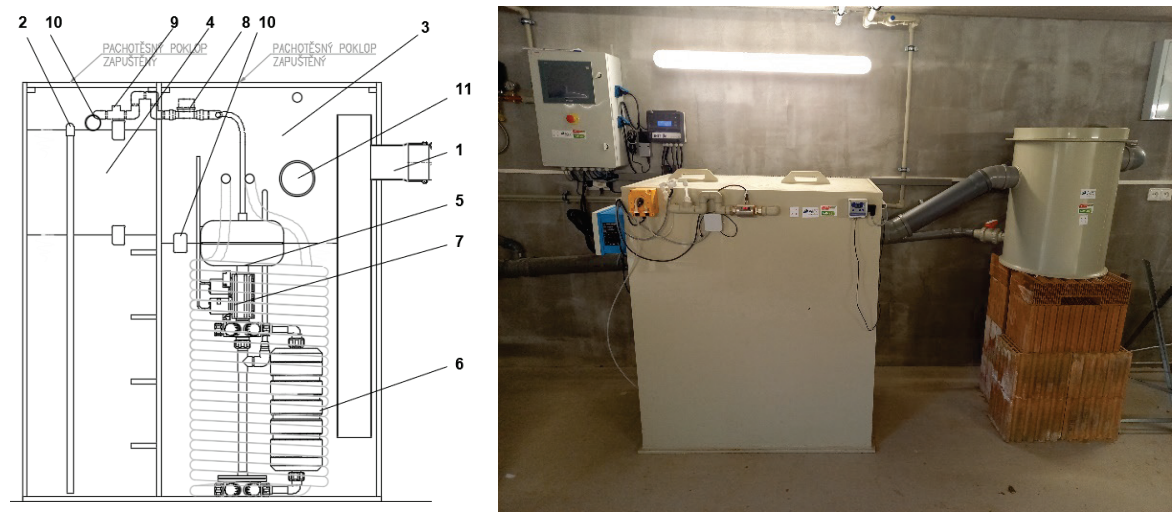

Obr. 2 Vlevo: Schéma technologie čištění (1 - přítok do prototypu z AN ŠV; 2 - odtah bílé vody; 3 - bioreaktor; 4 - akumulace bílé vody; 5 - membránová stanice; 6 - membrána; 7 - čerpadla; 8 - průtokoměr; 9 - dávkování chlornanu sodného; 10 - hladinový plovák; 11 - bezpečnostní přepad), vpravo: fotografie instalovaného prototypu.

Technologie pro čištění ŠV byla v rámci rodinného domu testována 74 dní s nepravidelným přítokem šedé vody, jejíž zdrojem byly odpadní vody z pračky, dvou sprch, vany, dvou umyvadel. Odpadní vody z kuchyně a myčky byly odváděny prímo do veřejné kanalizace. Výsledky analýzy ŠV na vstupu, bílé vyčištěné vody na

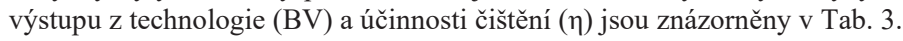

Tab. 3 Výsledky fyzikální a chemické analýzy odpadní vody z testování v reálných podmínkách.

\begin{tabular}{|c|c|c|c|c|c|c|c|}
\hline \multirow[b]{2}{*}{ OV } & \multirow[b]{2}{*}{ Ukazatel } & \multirow[b]{2}{*}{ MJ } & \multicolumn{5}{|c|}{ Odběr } \\
\hline & & & 1 & 2 & 3 & 4 & 5 \\
\hline ŠV & \multirow{3}{*}{$\mathrm{pH}$} & \multirow[b]{2}{*}{-} & 8,03 & 7,8 & - & - & - \\
\hline BV & & & 8,29 & 8,26 & 8,4 & 7,8 & 8,3 \\
\hline$\eta$ & & $\%$ & $-2,34$ & $-5,90$ & - & - & - \\
\hline ŠV & \multirow{3}{*}{ barva } & \multirow{2}{*}{$\mathrm{mg} \cdot 1^{-1} \mathrm{Pt}$} & $>225$ & 224 & $>225$ & 141 & $>225$ \\
\hline BV & & & 127 & 75 & 78 & 81 & 190 \\
\hline$\eta$ & & $\%$ & $\min .43,56$ & 66,52 & $\min .65,33$ & 42,55 & $\min .15,56$ \\
\hline ŠV & \multirow{3}{*}{ zákal } & \multirow{2}{*}{$\mathrm{ZF}(\mathrm{n})$} & 280 & 32,2 & 29,7 & 12,4 & 36 \\
\hline BV & & & 9,4 & 6,95 & 7,34 & 6,84 & 11,1 \\
\hline$\eta$ & & $\%$ & 96,64 & 78,42 & 75,29 & 44,84 & 69,17 \\
\hline ŠV & \multirow{3}{*}{ NL } & \multirow{2}{*}{$\mathrm{mg} \cdot \mathrm{l}^{-1}$} & 98 & 33 & 40 & 21 & 30 \\
\hline BV & & & 18 & 19 & 9 & 9 & 7 \\
\hline$\eta$ & & $\%$ & 81,63 & 42,42 & 77,50 & 57,14 & 76,67 \\
\hline$\breve{S} V$ & \multirow{3}{*}{$\mathrm{BSK}_{5}$} & \multirow{2}{*}{$\mathrm{mg} \cdot \mathrm{l}^{-1}$} & 84,6 & 65,2 & 56,5 & 34,5 & 66,5 \\
\hline BV & & & 6 & 8,2 & 5,5 & 6 & 16,5 \\
\hline$\eta$ & & $\%$ & 92,91 & 87,42 & 90,27 & 82,61 & 75,19 \\
\hline ŠV & \multirow{3}{*}{$\mathrm{CHSK}_{\mathrm{Cr}}$} & \multirow{2}{*}{$\mathrm{mg} \cdot \mathrm{l}^{-1}$} & 964 & 159 & 226 & 105 & 196 \\
\hline BV & & & 90 & 60 & 224 & 55 & 87 \\
\hline$\eta$ & & $\%$ & 90,66 & 62,26 & 0,88 & 47,62 & 55,61 \\
\hline ŠV & \multirow{3}{*}{ tenzidy (aniont) } & \multirow{2}{*}{$\mathrm{mg} \cdot \mathrm{l}^{-1}$} & 30,5 & 6,1 & 7,6 & 6,2 & 6,1 \\
\hline BV & & & 0,45 & 0,4 & 0,39 & 0,39 & 0,37 \\
\hline$\eta$ & & $\%$ & 98,52 & 93,44 & 94,87 & 93,71 & 93,93 \\
\hline
\end{tabular}

Aplikace prototypu pro čištění a znovuvyužití ŠV splnila s ohledem na ČSN ISO 20761 [3] podmínky pro ukazatele kvality bílé přečištěné odpadní vody pro využití k zavlažování tyto limity: $\mathrm{pH}, \mathrm{BSK}_{5}$ (pouze v prŕípadě limitů stanovených v Č́ně a USA). Při srovnání výsledků BV vody s limity pro splachování toalet byly splněny podmínky pro ukazatele $\mathrm{pH}, \mathrm{BSK}_{5}$ (pouze v případě limitů stanovených v Číně a Kanadě), NL (pouze v př́ípadě 
limitů stanovených v Kanadě). Ostatní ukazatele kvality BV pro splachování toalet nesplnily limity stanovené Kanadou, Č́́nou, Izraelem, Japonskem, Španělskem ani USA [4].

V průběhu testování byla provedena také regenerace membrán pro zajištění požadované kvality BV na odtoku z prototypu, nicméně výsledky analýzy BV i po tomto ošetření nesplnily všechny stanovené limity pro uvedené ukazatele [4].

\section{ZÁVĚR}

Předmětem tohoto příspěvku bylo představení výstupů z testování čištění šedé vody pomocí technologického procesu založeném na využití membránového bioreaktoru s mikrofiltračním membránovým modulem. V rámci testování byly v první etapě čištěny šedé vody na odtoku ze sprchového koutu v laboratoři výzkumného centra AdMaS. V druhé etapě byly pomocí MBR technologie čištěny neseparované šedé vody vznikající v reálných podmínkách rodinného domu.

Vzhledem k značným rozdílům kvality šedé vody na vstupu do technologického procesu v laboratoři a aplikaci $\mathrm{v}$ reálných podmínkách nelze srovnávat pouze účinnost čištění vztažené na jednotlivé ukazatele znečištění v šedé vodě a je nutné srovnat hodnoty ukazatelů na výstupu z technologického procesu s doporučenými hodnotami pro bílou odpadní vodu uvedenými v normě ČSN ISO 20761 [3]. V obou etapách testování však nebylo dosaženo kompletního splnění předepsaných limitů pro kvalitu bílé vody určené k opětovnému využití pro splachování toalet a zavlažování.

Při další implementaci MBR technologie je pro zlepšení fyzikálních, chemických a mikrobiologických vlastností vyčištěné BV doporučeno osazení ultrafiltrační membrány namísto testované mikrofiltrační membrány.

\section{Poděkování}

Tento článek byl vytvořen s finanční podporou TA ČR v rámci řešení projektu TJ02000190 Získávání a využití tepelné energie $\mathrm{z}$ odpadní vody v kombinaci s využitím vyčištěné vody, dále s podporou Specifického výzkumu Vysokého učení technického $\mathrm{v}$ Brně v rámci řešení projektu FAST-S-21-7424 Řešení aktuálních problémů vodního hospodářství měst a obcí.

\section{Použité zdroje}

[1] BOANO, F., CARUSO, A., COSTAMAGNA, E., RIDOLFI, L., FIORE, S., DEMICHELIS, F., GALVÃO, A., PISOEIRO, J., RIZZO, A., \& MASI, F. (2020). A review of nature-based solutions for greywater treatment: Applications, hydraulic design, and environmental benefits. Science of The Total Environment, 711. https://doi.org/10.1016/j.scitotenv.2019.134731

[2] FRIEDLER, E., HADARI, M. (2006). Economic feasibility of on-site greywater reuse in multi-storey buildings. Desalination, 190(1-3), 221-234. https://doi.org/10.1016/j.desal.2005.10.007

[3] ČSN ISO 20761. (2020). Opětovné využití vody v městských oblastech - Směrnice pro hodnocení bezpečnosti opětovného využití vody - Hodnocené ukazatele a metody (01.04.2020). Česká technická norma (ČSN)

[4] VELIKOVSKÁ, K.; MRAVCOVÁ, L.; ŠEVELA, P.; POLÁŠEK, P.; RAČEK, J.; HLAVÍNEK, P.; ŠVÁBOVÁ, M. Laboratorní testování účinnosti čištění a rekuperace tepelné energie šedé vody pro opětovné využití. Vodní hospodářství, 2021, roč. 71, č. 6, s. 3-11. ISSN: 1211-0760.

[5] RAČEK, Jakub. Metodika návrhu systému využití šedých vod ve vybraných objektech. Brno, 2016. 198 s., 2 přílohy, Dizertační práce. Vysoké učení technické v Brně, Fakulta stavební, Ústav vodního hospodářství obcí. Vedoucí práce doc. Ing. Jaroslav Raclavský, Ph.D.

[6] MINNESOTA RURAL WATER ASSOCIATION. (2001). Chapter19: Membrane Filtration. Minnesota Water Works Operations Manual, 1-12. Retrieved from http://www.mrwa.com/WaterWorksMnl/Chapter 19 Membrane Filtration.pdf

[7] STEPHENSON, T., BRINDLE, K., JUDD, S., \& JEFFERSON, B. (2000). Membrane Bioreactors for Wastewater Treatment, 3. Retrieved from https://www.amtaorg.com/Membrane_Bioreactors_for_Wastewater_Treatment.html 